Resenhas

\title{
Diferença na igualdade
}

\author{
Elogio da diferença: o feminino \\ emergente.
}

ROSISKA, Darcy de Oliveira.

Rio de Janeiro: Rocco, 2012. 167p.

A reedição de Elogio da diferença é muito bem-vinda, seja porque houve avanços desde 1991, ano da primeira edição, seja porque outros avanços propostos por Rosiska Darcy de Oliveira não foram buscados, quiçá por serem pouco conhecidos.

Se a bandeira clássica do feminismo foi a igualdade, a proposta de Darcy de Oliveira é a diferença. Não a diferença da opressão, não a diferença da inferioridade, mas o direito de ser igual sendo outro.

Se o feminismo sempre lutou pela igualdade de oportunidade entre homens e mulheres nas carreiras culturalmente masculinas, o que Darcy de Oliveira propõe é a igualdade de valor social entre essas carreiras e os trabalhos culturalmente femininos, pois seria um erro concordar com a premissa tácita de que as tarefas "femininas" são inferiores e seria um empobrecimento do horizonte civilizatório de todos a total terceirização dessas tarefas para as creches e outros serviços.

Se as tarefas tradicionalmente femininas são distintas das tarefas tradicionalmente masculinas, isso não quer dizer que elas sejam inferiores ou menos importantes. O prestígio social de umas deve ser igual ao das outras, sem que as tarefas sejam iguais. Deve haver diferença na igualdade e igualdade na diferença.

A meu ver, o desafio dessa proposta é explicar como se pode dar o devido valor aos papéis femininos sem abrir espaço para o discurso reacionário, o qual naturaliza e essencializa os papéis de mãe e de esposa do lar. Não poderia o reacio- nário dizer que está de acordo com o pós-feminismo de Darcy de Oliveira, dado que defende que as mulheres fiquem em casa, sem estudar ou trabalhar, só cuidando das crianças, dos veIhos e do esposo?

Uma parte da resposta a essa questão é simples. Por se tratar de um pós-feminismo, a proposta de Darcy de Oliveira pressupõe as conquistas feministas, isto é, não só Darcy de Oliveira pressupõe, contra o reacionário, que as mulheres devem ter espaço garantido, talvez até mesmo com cotas e discriminação positiva, nos mundos do trabalho e da educação. A ideia não é que as mulheres abandonem o mundo público e sejam encerradas no mundo privado. A ideia é que se reconheçam o valor e a importância fundamental do mundo privado e que se preserve este mundo. Assim, contra a ideologia reacionária, Darcy de Oliveira toma o voltar-se para o mundo privado como uma escolha, não como um destino, muito menos como um fardo.

Outra parte da resposta é mais complexa. Afinal, se a valorização do mundo íntimo e privado não viria da remuneração do "trabalho" de cuidar dos próximos, mas sim de uma gigantesca mudança civilizatória, na qual se estimularia os homens a buscarem as "carreiras" tradicionalmente femininas, não estar-se-ia esperando o impossível?

Ora, a proposta de Darcy de Oliveira é justamente que se espere e se imagine o "impossível" pois é a partir da invenção do "impossível" que se abrem novas possibilidades. É transformando e desorganizando - as opções abertas a homens e mulheres que se cria um mundo no qual a ação e o conhecimento femininos valem ao menos tanto quanto as carreiras e práticas tradicionalmente masculinas.

Assim, a proposta de Darcy de Oliveira é voltada para o futuro, mas com um olho no passado. Do passado se resgatam as atividades femininas com conotação pouco meritória, buscando a sua valorização no futuro. Sem tal projeto, 
é como se o feminino tivesse que ser definido segundo a régua masculina, e o problema todo é justamente que uma igualdade digna deste nome requer réguas diferentes para gêneros diferentes não porque um gênero é superior ou inferior ao outro, mas porque cada gênero tem uma métrica distinta, sendo a existência de cada escala por si mesmo um elemento rico e inegociável da vida em sociedade.

Darcy de Oliveira aponta para sinais claros de que há algo de desequilibrado na sociedade, apesar de haver mais oportunidade para as mulheres. Sim, agora as mulheres podem estudar e podem trabalhar, mas o mundo privado que serve de sustento e de plano de imanência para o mundo público do trabalho e do ensino ainda se apoia no núcleo familiar com uma mulher que cuida de todos, inclusive e principalmente do marido, que dá tanto trabalho quanto um filho. Esse desequilíbrio já é reconhecido na muito discutida jornada dupla de trabalho, mas pouco se fala sobre como lidar com essa questão. Por que não se fala disso? Talvez por se considerar natural que as mulheres cuidem de tarefas "menores", como a limpeza das crianças ou da casa. Mas de onde viria tal inferioridade? Do mero fato de essas tarefas tradicionalmente serem feitas por mulheres? Se assim for, o equilíbrio nos valores do cuidado privado e do trabalho público viria da escolha, pelos homens, dessas tarefas e "vocações" femininas. É exatamente o que Rosiska Darcy de Oliveira propõe.

César Schirmer dos Santos Universidade Federal de Santa Maria 